\title{
Introduction to the Eighth Annual Lecture
}

\author{
by Jannik Lindbæk*
}

The Geneva Association was formed in 1973 as an association of individuals in a leading position in the insurance world encompassing members from most European countries. Later a number of associated members from the United States have been invited to join the organisation. In the coming years a moderate extension of the membership is planned.

The aim of the organisation is to further the economic research in the areas of insurance, risk and uncertainty. Insurance is an important element in any modern industrialised society and a vital prerequisite for continued economic growth.

The insurance industry can be heavily affected by technological developments, and must be able to cope with the economic consequences of disasters of various kinds.

Thus the interface between the world of economic research and the insurance industry is of vital importance if the insurance industry is going to be able to continue to play its vital part in modern society.

One of the important activities of the Geneva Association is the Annual Lecture. Previous lectures have been held by prominent economists like Kenneth J. Arrow, Jacques Drèze, Martin Feldstein, Karl Borch, Joseph Stiglitz, Raymond Barre and Walter A. Weisskopf. Previously the Lectures have been given at institutions like the London School of Economics, the Polytechnicum of Zurich and the Wharton School of Finance in Philadelphia.

It is therefore with great pleasure we welcome the Geneva Association to the University of Oslo where this year's lecure will be held by Professor Edmond Malinvaud from Paris. The University of Oslo has important traditions in the field of economic research and this opportunity to hear Professor Malinvaud and the other Discussants has been eagerly anticipated.

* Vice-President of the Geneva Association, Managing Director of the Storebrand-Norden Group, Oslo. 


\title{
EIGHTH ANNUAL LECTURE of the GENEVA ASSOCIATION
}

with the collaboration of THE UNIVERSITY OF OSLO

\author{
by
}

\section{Professor EDMOND MALINVAUD}

\section{on \\ THE ECONOMICS OF UNEMPLOYMENT INSURANCE}

\section{MONDAY JUNE 4TH, 1984 at 15.00 (3:00 p.m.)}

\section{THE UNIVERSITY OF OSLO \\ Blindernveien, Blindern}

FAKULTETSRÅDSALEN, Administrasjonsbygget

Chairman: Professor Karl BORCH, Norges Handelshøyskole, Bergen

Introduction: Mr. Jannik LINDBÆK

Member of the Board of the Geneva Association

Managing Director of the STOREBRAND-NORDEN Group, Oslo

Discussants: Professor Michael BEENSTOCK,

The City University Business School, London

Dr. Anders BJØRKLUND, Industriens Utredningsinstitut, Stockholm Professor Stephen NICKELL, The London School of Economics Professor Erling STEIGUM, Norges Handelshøyskole, Bergen 